\title{
Identification's Mediatory Role on Communication and Job Satisfaction Relationship in Mergers
}

\author{
Yurdagül Meral
}

\begin{abstract}
New identification after merger has an important role for success in mergers.
This study's purpose is to investigate the relations between communication, identification and job satisfaction. Furthermore to show the communication and identification's effect on job satisfaction and the mediatory role of identification among communication and job satisfaction.

Participants of the research were reached by convenient sampling, in a bank merger, after the merger $(N=143)$. The reliability, validity, normality, correlation analysis uze bootstrap analysis were used to find out the mediatory role of the new identification after the merger.

As a result, new identification after the merger, has a mediatory effect on the relationship between communication and job satisfaction in bank mergers.
\end{abstract}

Keywords: Communication, Mediation, Bootstrapping, Job Satisfaction, New Identification After Merger, Bank Mergers, Mergers

\section{INTRODUCTION}

The aim of this paper is to find out communication's effect on new identification after merger and job satisfaction in mergers. Correlations among these variables and the direction of the relations are investigated. Furthermore new identification after merger's indirect (mediating) effect on the relationship between communication and job satisfaction is investigated.

Employees' identification with their companies effect their job satisfaction positively. Depending on their identification or disidentification levels, their job satisfactions are effected positively or negatively. Employees' identification with their company has an indirect effect on the relationship between communication and job satisfaction.

The purpose of the study is to find out the replies to the following questions;

a) Does communication climate effect job satisfaction?

b) Does communication climate effect new identification after merger?

c) Does new identification after merger effect job satisfaction?

d) Does new identification after merger indirectly effect (mediate) the relationship between communication climate and job satisfaction?

In other words does the new identification after merger has a mediatory role on the relationship between communication and job satisfaction of the employees' working in the merged bank after the bank merger.

In context with these questions, the effects of identification and communication on job satisfaction are investigated in a case study of a bank merger. Furthermore the indirect effect and if any size of the indirect effect is also investigated. The research is based on the author's unpublished phd dissertation, (Istanbul university, June, 2015)

The model and the hypothesis is defined as follows:

Hypothesis: Communication climate effects job satisfaction positively via new identification after the merger.

- Communication climate effects new identification after merger positively.

- Communication climate effects job satisfaction positively. 
- New identification after merger effects job satisfaction positively.

- New identification has a mediatory role on the relationship between communication climate and job satisfaction.

The mediatory variable's (new identification after the merger's) indirect (mediating) effect on the relationship between the dependent variable (job satisfaction) and independent variable (communication climate) is investigated.

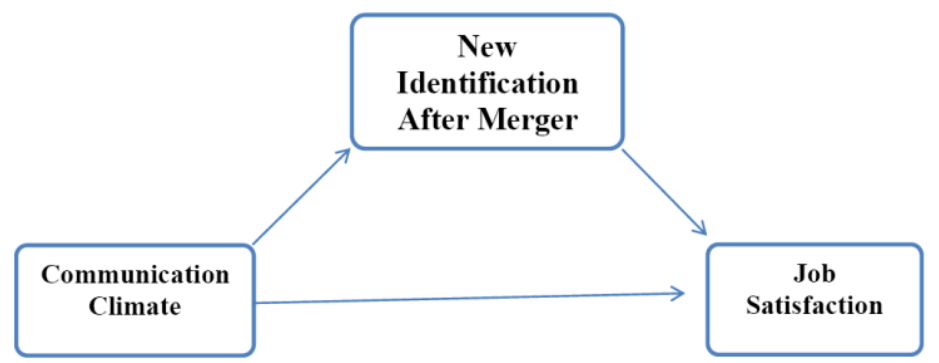

Figure1. Hyhothesis Model "New identification after merger has in indirect (mediating) positive effect on the relationship between communication climate and job satisfaction in mergers"

\section{CoMmunication EFFECTS in Mergers}

Communication is one of the most appropriate tools management can use to succed in mergers ${ }^{1}$.

Communication effects in mergers can be summarized as follows ${ }^{2}$;

- Communication effects identification positively in mergers ${ }^{3}$.

- Communication effects belonging to the organization positively ${ }^{4}$.

- Communication contributes positively during adoptation period ${ }^{5}$.

- Communication decreases negative reactions to changes and mergers ${ }^{6}$.

Information sharing is a critical important factor during mergers because the employees' need for the information can be compared to the uncertainty of an employee who has just started the job. Stress and uncertainty perception is reduced with correct information and open communication. Reduction in uncertainty is critical for success in changes ${ }^{7}$.

Unsuccessful communication usually increases anxiety and uncertainty about future especially during change periods ${ }^{8}$.Communication about changes usually are usually not sufficient to meet employees' expectations therefore especially during stressfull changes periods, communication is a critical factor for success ${ }^{9}$.

1 Van Knippenberg, D. and E. Van Leeuwen (2001). 'Sense of continuity as the key to postmerger identification'. In: M. A. Hogg and D. J. Terry (eds), Social identity processes in organizational contexts, pp. 249-264. Psychology Press, Philadelphia.

${ }^{2}$ Schweiger, David M., and Angelo S. Denisi. "Communication with employees following a merger: A longitudinal field experiment." Academy of management journal34.1 (1991): 110-135.

${ }^{3}$ Bartels, Jos, Ad Pruyn, and Menno Jong. "Employee identification before and after an internal merger: A longitudinal analysis." Journal of occupational and organizational psychology 82.1 (2009): 113-128

${ }^{4}$ Cheney, George. "On the various and changing meanings of organizational membership: A field study of organizational identification." Communications Monographs 50.4 (1983): 342-362.

${ }^{5}$ Tüzün, İpek Kalemci, and İrfan Çağlar. "Örgütsel Özdeşleşme Kavramı ve İletişim Etkinliği İlişkisi." Journal of Yasar University 3.9 (2008): 1011-1027.

${ }^{6}$ Schweiger, David M., and James P. Walsh. "Mergers and acquisitions: An interdisciplinary view." Research in personnel and human resources management 8 (1990): 41-107.

${ }^{7}$ Leiter, Michael P., and Christina Maslach. "The impact of interpersonal environment on burnout and organizational commitment." Journal of organizational behavior 9.4 (1988): 297-308.

${ }^{8}$ Kanter, Rosabeth Moss. Challenge of organizational change: How companies experience it and leaders guide it. Simon and Schuster, 2003.

9 Schweiger, David M., and Angelo S. Denisi. "Communication with employees following a merger: A longitudinal field experiment." Academy of management journal34.1 (1991): 110-135. 
However if management uses communication to draw employees' attention from reality to different subjects by manipulating than it becomes worse it even creates more reaction against mergers. It it is not easy to create new identification with merged company, frequent and open communication is necessary ${ }^{10}$. Management must use open and sincere communication to empower the new identification ${ }^{11}$. Managers must focus on 'we', instead of 'I' and emphasize the common points with the employees, try sincerely to create an open communication climate ${ }^{12}$ as communication effects new identification and job satisfaction positively.

However in some researches about mergers and acquisitions, it is advised to avoid communication about realities because such communication warns the competitors and enables the employees' to quit instead of a stressful merger process. Furthermore, such communication threatens the flexibility of the management against potential changes during merger and acquisition process. However in another related research, it is found that informing the employees prior to the mergers and acquisitions is not positively related with turn over or coming late or production ${ }^{13}$.

In another research it was found that there was no relation between mergers success and communication $^{14}$ and also in another research results were not significant on communication's effect on identification in mergers ${ }^{15}$.

\section{Communication AND IdENTIFICATION}

Communication's effect on mergers or on organizational changes is widely accepted, however communication's role in identification process is not clarified sufficiently ${ }^{16}$.

Two cultural functions of corporate communication's are;

1. 1-to inform the employees about the corporate culture and

2. 2-to entegrate them with the corporate culture. Identification is created via identifying with the corporate culture, corporate communication and living with it ${ }^{17}$.

Satisfaction with content of corporate messages, communication climate and how information is transmitted is important for employees' identification ${ }^{18}$. Identification process starts with content of communication by clarifying the organization's goals, values and successes ${ }^{19}$.

Organizations sharing their own identity (goals, values, successes) is also important for employees' identification ${ }^{20}$. Clarification of organization's norm and values and clear definition of expected role provides employee's employee's classification with the organization while at the same time providing employees to be interested with the organization empowering their identification ${ }^{21}$.

\footnotetext{
${ }^{10}$ Tim A. Grice , Cynthia Gallois , Elizabeth Jones , Neil Paulsen \& Victor J. Callan (2006): "We Do It, but They Don't": Multiple Categorizations and Work Team Communication, Journal of Applied Communication Research, 34:4, 331348

${ }^{11}$ Vaara, E. (2003). 'Post-acquisition integration as sensemaking: Glimpses of ambiguity, confusion, hypocrisy, and politicization', Journal of Management Studies, 40, pp. 859-894.

${ }^{12}$ Hurley, Robert F. "The decision to trust." Harvard Business Review84.9 (2006): 55-62

${ }^{13}$ Leana, Carrie R., and Daniel C. Feldman. "When mergers force layoffs: Some lessons about managing the human resource problems." Human Resource Planning12.2 (1989): 123-140.

${ }^{14}$ Cornett-DeVito, Myrna M., and Paul G. Friedman. "Communication Processes and Merger Success An Exploratory Study of Four Financial Institution Mergers." Management Communication Quarterly 9.1 (1995): 46-77.

${ }^{15}$ Bachman, B. A. (1993). An intergroup model of organizational mergers. Unpublished doctoral dissertation, University of Delaware, Newark, USA

${ }^{16}$ Paulsen, Neil., et al. "Identification, discourse, and intergroup communication in organizational contexts." Unpublished manuscript, University of Queensland, Brisbane (2004).

${ }^{17}$ Kreps, Gary L. Organizational communication: Theory and Practice. New York: Longman, 1990.

${ }^{18}$ Turner, John C., et al. Rediscovering the social group: A self-categorization theory. Basil Blackwell, 1987.

${ }^{19}$ Cheney, George. "The rhetoric of identification and the study of organizational communication." Quarterly Journal of Speech 69.2 (1983): 143-158.

${ }^{20}$ Lawler, Edward E., and Susan A. Mohrman. "With HR help, all managers can practice high-involvement management." Personnel 66.4 (1989): 26-31.

${ }^{21}$ Dutton, Jane E., Janet M. Dukerich, and Celia V. Harquail. "Organizational images and member identification." Administrative Science Quarterly (1994): 239-263.
} 
Research findingsshow that communication climate effects new identification after merger and job satisfaction positively and new identification has a mediatory role between communication climate and job satisfaction.

The results are in compliance with literature.

Communication during merger process effects identification after merger ${ }^{22}$.

Communication climate effects identification and job satisfaction positively in mergers ${ }^{23}$.

Identification motivates communication and via communication decreases the reactions to changes ${ }^{24}$.

In a research about bank mergers, it is found out that as communication has increased during merger process, the targeted bank employees' anxietyhas decreased ${ }^{25}$

Communication is an important factor effectingemployees' identification with their organization ${ }^{26}$.

\section{THE RESEARCH}

With a case study in the banking sector, communication effects on new identification after merger and job satisfaction in mergers are investigated. Furthermore the mediating (indirect) effect of new identification after merger on the relationship between communication and job satisfaction is investigated.

The research was done after the merger with the employees of the merged bank, who have experienced the merger. The scale used to measure the variables was 5 points Likert type, with replies ranging as: 1-Certainly Disagree 2-Disagree 3-Neither agree, nor disagree 4-Agree 5-Certainly.

The results from the data received from the participants were analyzed with SPSS 21.0. The data analysis (validity, reliability, correlation, normality and regression-bootstrapping method is used to measure the mediating effect) results are as follows.

\section{Sampling:}

The survey form used to collect the data is based on various sources in the literature. The participants $(N=143)$ were reached by convenient sampling procedure, and the 143 surveys received from the merged bank participants by convenient sampling procedure is acceptable for sampling size ${ }^{27}$.

\section{Variables and Scales used:}

There are three groups of variables,

- independent variable (communication climate),

- dependent variable (job satisfaction) and

- the mediator variable (new merger after identification).

Independent Variable: Communication Climate Scale was measured with question form was based on Dennis ${ }^{28}$ and Smidts et al. ${ }^{29}$ Scales with questions;

\footnotetext{
${ }^{22}$ Haslam, S. Alexander, Clare Powell, and John Turner. "Social Identity, Self-categorization, and Work Motivation: Rethinking the Contribution of the Group to Positive and Sustainable Organisational Outcomes." Applied Psychology49.3 (2000): 319-339.

${ }^{23}$ Smidts, Ale, Ad Th H. Pruyn, and Cees BM Van Riel. "The impact of employee communication and perceived external prestige on organizational identification." Academy of management journal 44.5 (2001): 1051-1062.

${ }^{24}$ Van Knippenberg, Daan, and Naomi Ellemers. "Social Identity and Group Performance." Social identity at work: Developing theory for organizational practice (2003): 29.

${ }^{25}$ Mishra, Jitendra, and Molly A. Morrissey. "Trust in employee/employer relationships: A survey of West Michigan managers." Public Personnel Management (1990).

${ }^{26}$ Riordan, Christine M., and Elizabeth W. Weatherly. "Defining and measuring employees' identification with their work groups." Educational and Psychological Measurement 59.2 (1999): 310-324.

${ }^{27}$ Altunışık, Remzi, et al. Sosyal bilimlerde araştırma yöntemleri: SPSS uygulamalı. Sakarya Yayıncılık, 2010.

${ }^{28}$ Dennis, Harry Sutphen. A Theoretical and Empirical Study of Managerial Communication Climate In Complex Organizations. (1974).
} 
a) Generally speaking, everyone is honest with one another.

b) If I talk with colleagues, I feel I am being taken seriously.

c) Colleagues genuinely listen to me when I say something.

The statements were based on Dennis ${ }^{30}$, Alutto ve Vredenburgh ${ }^{31}$, Downs and Hazen ${ }^{32}$, Falcione et.al. ${ }^{33}$ scales and generally related with open communication perception (vertical communication that is from management to employees' and from employees to management) is measured.

- trust to management with statement ('Generally speaking, everyone is honest with one another.'),

- participation in decision making with statement ('Colleagues genuinely listen to me when I say something.') and

- support with statement ('If I talk with colleagues, I feel I am being taken seriously.').

Other scales other than Dennis ${ }^{34}$ used in communication scale measures are;

- "Various Communication Investigations" scale by Greenbaum, Clampitt, Willihnganz ${ }^{35}$,

- Organizational Communication Questionnaire-OCQ scale by Roberts and O'Reilly ${ }^{36}$,

- CommunicationAuditQuestionnaire-CAQ by Wiio ve Helsila ${ }^{37}$,

- Communication Satisfaction Questionnaire by Downs ve Hazen ${ }^{38}$,

- International Communication Audit- ICA, Goldhaber ve Rogers ${ }^{39}$,

- Communication Audit by Hamilton ${ }^{40}$,

- Communication Scale by Gupta, Govindarajan ${ }^{41}$ and

- Interpersonal Communication Satisfaction Inventory-ICSI scale by $\mathrm{Hecht}^{42}$

${ }^{29}$ Smidts, Ale, Ad Th H. Pruyn, and Cees BM Van Riel. "The impact of employee communication and perceived external prestige on organizational identification." Academy of management journal 44.5 (2001): 1051-1062.

${ }^{30}$ Dennis, Harry Sutphen. A Theoretical and Empirical Study of Managerial Communication Climate In Complex Organizations. (1974).

${ }^{31}$ Alutto, J.A. and Vredenburgh, D.J. (1977). 'Characteristics of decisional participation by nurses', Academy of Management Journal, 20, 341-347.

${ }^{32}$ Downs, Cal W., and Michael D. Hazen. "A factor analytic study of communication satisfaction." Journal of business communication 14.3 (1977): 63-73.

${ }^{33}$ Falcione, Raymond L., Lyle Sussman, and Richard P. Herden. "Communication climate in organizations." Handbook of organizational communication: An interdisciplinary perspective (1987): 195-227.

${ }^{34}$ Dennis, Harry Sutphen. A Theoretical and Empirical Study of Managerial Communication Climate In Complex Organizations. (1974).

${ }^{35}$ Greenbaum, H., Clampitt, Pb., an Willhnganz, S., (1988). Organizationnal communication: An examination of four instruments. Management Communication Quarterly, 2, 245-282.

${ }^{36}$ Roberts, Karlene H., and Charles A. O'Reilly. "Failures in upward communication in organizations: Three possible culprits." Academy of Management Journal 17.2 (1974): 205-215

${ }^{37}$ Wiio, Osmo A., and Martti Helsila. "Auditing communication in organizations: A standard survey, LTT communication audits." Finnish Journal of Business Economics4.1 (1974): 303-315.

${ }^{38}$ Downs, Cal W., and Michael D. Hazen. "A factor analytic study of communication satisfaction." Journal of business communication 14.3 (1977): $63-73$.

${ }^{39}$ Goldhaber, Gerald M. "Organizational communication [by] Gerald M. Goldhaber." (1974).

${ }^{40}$ Hamilton, Seymour. A communication audit handbook: helping organizations communicate. Pitman, 1987.

${ }^{41}$ Gupta, Anil K., and Vijay Govindarajan. "Knowledge flows within multinational corporations." Strategic management journal21.4 (2000): 473-496. 
- Dependent Variable: Job Satisfaction Scale, two statements were based on Hackman and Oldham $^{43}$

a) Generally speaking, I am very satisfied with this job.

b) I am satisfied with the feeling to do something meaningful with my job.

- Mediatory Variable: New Identification After Mergerscale, three statements were based on Knippenberg and et $\mathrm{al}^{44}$ scale.

a) I identify myself with my new bank.

b) When someone criticizes my new bank, it feels like a personal insult.

\section{The Reliability Analysis:}

The cronbach alpha values of the variables are between 0.67 and 0.91 , of which the values are acceptable because they are over 0.60 which is the acceptable minimum lowest criteria ${ }^{45}$.

- New identification after bank merger scale Cronbach Alpha value:0.678,

- Job satisfaction scale Cronbach Alpha value:0.691,

- Communication climate scale Cronbach Alpha value:0.887,

\section{The Content Validity:}

The scales used to measure the variables in the model are based on different scales used in the literature. To clarify the statements used in the survey form, the Turkish translation of the question form was into English.Then the translated version was compared with the original statements and minor changes were done to clarify the staments arising from translation differences. Consulting to the academicians, final version was used.

\section{The Construct Validity (Factor Analysis):}

The Principal Components Analysis was used for construct validity for each variable. For measures of sampling adequacy (MSAs):

Kaiser-Meyer-Olkin (KMO) (should be > .5) and

Bartlett's test of sphericity (should be significant 0,05 ) was used.

Total variance explained over 0.50 percent criterion is used.

\section{New Identification After Bank Merger (Mediator) Variable:}

Kaiser - Meyer - Olkin (KMO) value: 0.66.

Bartlett's test of sphericity is over 0,50 percent with significant 0,05 .

Total variance explained: $\% 70.421$.

Job Satisfaction (Dependent) Variable:

Kaiser - Meyer - Olkin (KMO) value : 0.50

Bartlett's test of sphericity value is over 0,50 qercent with significant 0,05

Total variance explained: \%76.656.

\section{Communication Climate(Independent) Variable:}

Kaiser - Meyer - Olkin (KMO) value : 0.71

\footnotetext{
${ }^{42}$ Hecht, Michael L. "The conceptualization and measurement of interpersonal communication satisfaction." Human Communication Research4.3 (1978): 253-264.

${ }^{43}$ Hackman, J. Richard, and Greg R. Oldham. Work redesign. (1980).

${ }^{44}$ Van Knippenberg, Daan, et al. "Organizational identification after a merger: A social identity perspective." British Journal of Social Psychology 41.2 (2002): 233-252.

${ }^{45}$ Punch, Keith F. Introduction to social research: Quantitative and qualitative approaches. Sage, 2013.
} 
Bartlett's test of sphericity value is over 0,50 percent with 0,05 significance.

Total variance explained $\% 82.177$.

\section{RESEARCH RESULTS}

Research was done in the banking sector, after the merger. The participants were the ones who experienced merger process who were working in the banks before the merger.

\section{Participants Demographic Variables}

51 percent was between 31 and 40 years old, 32.2 percent between 20 and 30 age group of whom 56.6percent was married.

70.6 percent had university degree and 11.9 percent had post graduate degree.

47.6 percent had 1 to 5 years pre-merger bank experience

55.9 percent of the participants were female and 39.9 percent were male.

\section{Data Normality Distribution Analysis}

If the sample is less than 50, Shapiro Wilks, if more than 50 Kolmogorov-Smirnov test is used to find out the distribution of the data ${ }^{46}$. As a result of the Kolmogorov-Smirnov test, the data is not normally distributed because $(p<0.05)$ if the $p$ value were less than $(p>0,5)$ than it would indicate that the data were normally distributed. As the data is not normally distributed, the analysis are done with nonparametric techniques.

\section{Spearman Correlation Analysis}

As the data is not distributed normally, Spearman correlation analysis was used.

Spearman correlation analysis results show that there is a significant correlation among the variables communication climate, new identification after merger and job satisfaction.

\section{Bootstrapping Mediation AnALysis RESults}

The regression analysis of the hypothesis was done via bootstrapping analysis method ${ }^{47}$.

"Communication climate effects job satisfaction positively via new identification after merger."

Bootsrapping analysis results are shown in the figure;

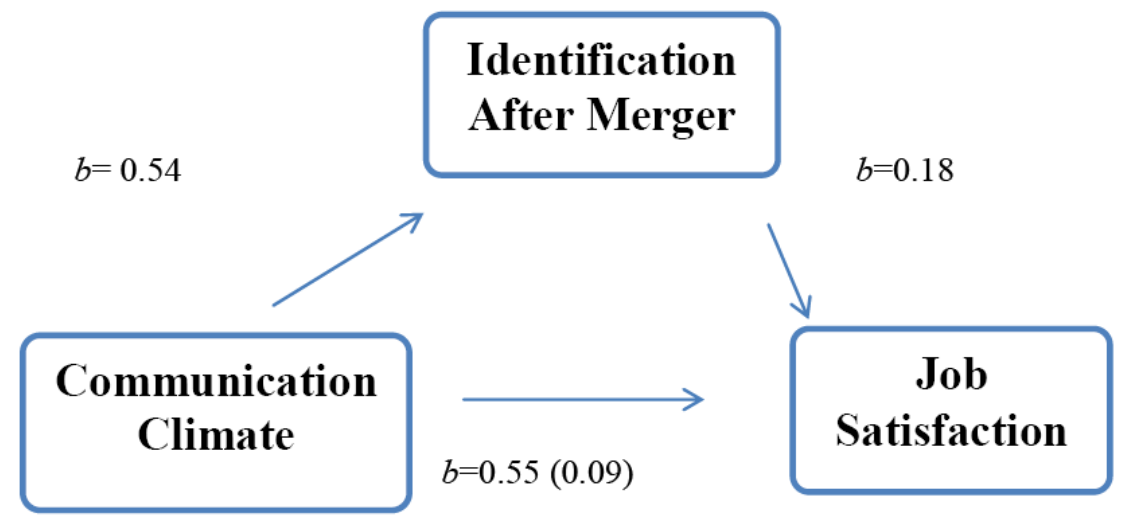

Figure2. Communication Climate Effects Employees' Job Satisfaction via New Identification After Merger

Findings indicate that communication climate effects job satisfaction via new identification after merger significantly,

$b=0.099$, BCa CI [0.027, 0.217].

The indirect effect is maximum about 10,4 percent

\footnotetext{
${ }^{46}$ Andy Field, a.g.e.p.93

${ }^{47}$ Hayes, Andrew F. Introduction to mediation, moderation, and conditional process analysis: A regression-based approach. Guilford Press, 2013.
} 
(Kappa-squared) $\kappa^{2}=0.104, \quad 95 \% \quad$ BCa CI [.278, .209].

Which verifies the hypothesis that is 'communication climate, effects job satisfaction positively via new identification after merger'

As a result,

- the independent variable (communication climate)'s indirect (mediating) effect on dependent variable (job satisfaction) via mediator variable (new identification) is investigated and the mediating effect of new identification after the merger is found on the relationship between the communication climate and the job satisfaction.

\section{Hypothesis : Communication climate effects job satisfaction positively via new identification after merger,}

is verified as given with the results below.

- There is a positive and significant relationship between the communication climate and the mediator variable the new identification after merger $(b=0.54, \mathrm{t}=6.60, \mathrm{p}=0,00)$.

- $R^{2}$ value shows that communication climate explains 24 percent of the variance on the relationship of new identification after the merger.

- The effect of both communication climate and new identification after the merger on the job satisfaction together has a positive and significant effect on job satisfaction.

$(b=0.46, \quad \mathrm{t}=5.75, \quad \mathrm{p}=0.00)$.

- The new identification after merger effects job satisfaction positive and significantly as below $(b=0.18, \quad \mathrm{t}=2.58, \quad \mathrm{p}=0.011)$.

- Communication climate on its own (that is without the mediator variable new identification after merger) effects job satisfaction positively and significantly

$(b=0.55, \quad \mathrm{t}=7.85, \quad \mathrm{p}=0.00)$.

- Total Effect: Communication climate on its own effects job satisfaction significantly.

- Direct Effect (relation with identification): Communication climate's direct effect on job satisfaction is significant.

- Indirect (Mediating) Effect: Communication climate's effect on job satisfaction via the new identification after merger (indirect/mediating effect) is $(b=0.992)$, with 95 percent confidence interval between 0,027 and 0,217 values and as these values do not cover zero shows that there is mediating effect. That is the new identification after merger is mediating the relationship between communication climate and jobsatisfaction.

- The new identification after merger's mediating effect results;

$\mathrm{b}=.099, \quad 95 \% \quad \mathrm{BCa} \quad \mathrm{CI} \quad[.028, .217]$,

As the bootstrap regression analysis results do not cover the zero value, it shows that the new identification after merger has a significant mediating effect on the relation between the communication climate and the job satisfaction and the confidence intervals and the effects value is;

$\mathrm{K}^{2}$ (Kappa-square) value $\kappa^{2}=.104,95 \%$ BCa CI [.278, 209].

$\kappa^{2}$ (Kappa-squared) value shows that the new identification after merger's mediating effect is about maximum 10,4 percent on the relationship of communication climate and job satisfaction.

\section{DISCUSSION}

Our research was conducted in banking sector and as information sharing is prohibited by law in the sector, to overcome this in the cover letter of the question form the participants were informed that the necessary consent has been obtained and that the information given will only be used for research purposes and will not be used with any other third party. 
As the research was done on a case study of two banks after the merger, the evaluations were based only with this research and can not be generalized out of this research.

In merger literature, there are limited papers covering before and after merger, as this research was done only after the merger as well.

Although there is a limitation that during the time passed after the merger, participants remembering positive memories or not remembering very well the events, the replies might have been effected however as long as the research is done within a few years after the merger, there is no subjectivity or correctness problem ${ }^{48}$.

The research results show that the new identification after the merger and communication climate effect job satisfaction positively and the new identification after merger has an mediating effect on the relationship between communication climate and job satisfaction.

To succeed in mergers, managers must focus on communication, which effects job satisfaction and new identification positively as in our research results, which verify that communication climate effects new identification and job satisfaction positively and the new identification after merger has a mediating effect on the relationship between communication climate and job satisfaction.

The results are in compliance with the literature ${ }^{49}$.

Communication reduces the negative perception of mergers among employees ${ }^{50}$.

Companies focusing on communication are 13 percent more successful comparing to other successful companies in mergers ${ }^{51}$.

The employees are main factor of success in mergers ${ }^{52}$ therefore management's focusing on employees' satisfaction is very important. The uncertainty and great organizational changes of merger process and employees' stress and anxiety arising from the uncertainty and changes are given as failure reasons of mergers in literature, therefore management's focusing on these reasons and solving

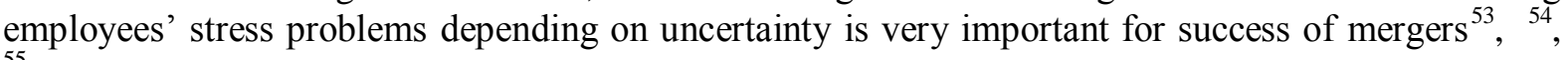
55

New identification after merger is another major problem of the managementin mergers. In mergers, usually one of the partners is more powerful than the other partner and usually for the employees' of the less powerful partner,merger is not different from acquisition, where the structure of the company is so changed that for these employees it usually takes five to seven years to adopt and be assimilited in the new merged company ${ }^{56},{ }^{57}$.

\footnotetext{
${ }^{48}$ Gutek, Barbara A. "On the accuracy of retrospective attitudinal data." Public Opinion Quarterly 42.3 (1978): 390-401.

${ }^{49}$ Smidts, Ale, Ad Th H. Pruyn, and Cees BM Van Riel. "The impact of employee communication and perceived external prestige on organizational identification." Academy of Management journal44.5 (2001): 1051-1062.

50 Schweiger, David M., and Angelo S. Denisi. "Communication with employees following a merger: A longitudinal field experiment." Academy of management journal34.1 (1991): 110-135.

${ }^{51}$ KPMG Report, 2010, Post Merger People Integration, (çevrimiçi)

https://www.kpmg.com/IN/en/IssuesAndInsights/ArticlesPublications/Documents/Post\%20Merger\%20People\% 20Integration.pdf 24.12.2014

${ }^{52}$ Cartwright, D. and C. L. Cooper (1992). Mergers and acquisitions:the human factor. Butterworth-Heinemann, Oxford.

${ }^{53}$ van Dick, R., Ullrich J, Tissington, P.A., Working Under a Black Cloud: How to Sustain Organizational Identification after a Merger, British Journal of Management, Vol. 17, S69-S79 (2006)

${ }^{54}$ Cartwright, S. and S. Panchal (2001). 'The stressful effects ofmergers and acquisitions'. In: J. Dunham (ed.),
} Stress in the workplace: Past, present and future, pp. 67-89. Whurr, Publishers, London.

${ }^{55}$ Hogan, E. A. and L. Overmyer-Day (1994). 'The psychology of mergers and acquisitions'. In: C. L. Cooper and L. T. Robertson (eds), International Review of Industrial and Organizational Psychology, 9, pp. 247281. Wiley, Chichester.

${ }^{56}$ Van Dick, Rolf, Johannes Ullrich, and Patrick A. Tissington. "Working Under a Black Cloud: How to Sustain Organizational Identification after a Merger." British Journal of management 17.S1 (2006): S69-S79. 
Relationships between communication climate, new identification after merger and job satisfaction are investigated. Effects of communication climate on new identification after merger and on job satisfaction in mergers are also investigated in this study. Furthermore the indirect effect of new identification's indirect (mediating) effect on the relationship between communication climate and job satisfaction is also investigated.

New identification after merger is used as a mediator variable in the model. To measure mediation, the independent variable must effect the mediating variable and the dependent variable and the relationship between the dependent and the independent variable must be effected by the mediator variable.

The scales of variables used in the research were adopted from the scales used in the literature and the data was evaluated according to this.

This research will be of assistance for researchs about factors effecting job satisfaction like communication and new identification after merger which is related with success of mergers. Future researches to find out other factors effecting job satisfaction covering pre-merger processes along post-merger processes will contribute to success of mergers.

The research findings show that new identification aftermerger has an indirect (mediating) effect on the relationship between communication climate and job satisfaction and being able to measure the indirect effect size differentiates this research.

\section{CONClusion}

Research result shows that there is a mediatory role of new identification after the merger on the relationship between communication climate and job satisfaction.

In this case study of bank mergers, findings indicate that communication climate effects job satisfaction positively, furthermore there is an indirect (mediating) effect of new identification after merger on job satisfaction increase by the communication climate.

The research results verify that job satisfaction is very important for success in mergers. Communication climate effects job satisfaction and new identification after merger. New identification after merger has a mediatory role on the relationship between communication climate and job satisfaction.

For mergers success, managers must consider factors effecting job satisfaction like communication and new identification in future.

\section{REFERENCES}

Altunışık, Remzi, et al. Sosyal bilimlerde araştırma yöntemleri: SPSS uygulamalı. Sakarya Yayınc1lık, 2010.

Andy Field, Discovering Statistics with SPSS

Bachman, B. A. (1993). An intergroup model of organizational mergers. Unpublished doctoral dissertation, University of Delaware, Newark, USA

Bartels, Jos, Ad Pruyn, and Menno Jong. "Employee identification before and after an internal merger: A longitudinal analysis." Journal of occupational and organizational psychology 82.1 (2009): 113-128

Cartwright, D. and C. L. Cooper (1992). Mergers and acquisitions:the human factor. ButterworthHeinemann, Oxford.

Cartwright, S. and S. Panchal (2001). 'The stressful effects ofmergers and acquisitions'. In: J. Dunham (ed.), Stress in the workplace: Past, present and future, pp. 67-89. Whurr, Publishers, London.

Cheney, George. "On the various and changing meanings of organizational membership: A field study of organizational identification." Communications Monographs 50.4 (1983): 342-362.

Cheney, George. "The rhetoric of identification and the study of organizational communication." Quarterly Journal of Speech 69.2 (1983): 143-158.

\footnotetext{
${ }^{57}$ Marks, Mitchell Lee, and Philip H. Mirvis. "Track the impact of mergers and acquisitions." Personnel
} Journal 71.4 (1992): 70-79. 
Cornett-DeVito, Myrna M., and Paul G. Friedman. "Communication Processes and Merger Success An Exploratory Study of Four Financial Institution Mergers." Management Communication Quarterly 9.1 (1995): 46-77.

Dutton, Jane E., Janet M. Dukerich, and Celia V. Harquail. "Organizational images and member identification." Administrative Science Quarterly (1994): 239-263.

Gutek, Barbara A. "On the accuracy of retrospective attitudinal data." Public Opinion Quarterly 42.3 (1978): 390-401.

Haslam, S. Alexander, Clare Powell, and John Turner. "Social Identity, Self-categorization, and Work Motivation: Rethinking the Contribution of the Group to Positive and Sustainable Organisational Outcomes." Applied Psychology49.3 (2000): 319-339.

Hayes, Andrew F. Introduction to mediation, moderation, and conditional process analysis: A regression-based approach. Guilford Press, 2013.

Hogan, E. A. and L. Overmyer-Day (1994). 'The psychology of mergers and acquisitions'. In: C. L. Cooper and L. T. Robertson (eds), International Review of Industrial and Organizational Psychology, 9, pp. 247-281. Wiley, Chichester.

Hurley, Robert F. "The decision to trust." Harvard Business Review84.9 (2006): 55-62

Kanter, Rosabeth Moss. Challenge of organizational change: How companies experience it and leaders guide it. Simon and Schuster, 2003.

KPMG Report, 2010, Post Merger People Integration, (çevrimiçi)

Kreps, Gary L. Organizational communication: Theory and Practice. New York: Longman, 1990.

Lawler, Edward E., and Susan A. Mohrman. "With HR help, all managers can practice highinvolvement management." Personnel 66.4 (1989): 26-31.

Leana, Carrie R., and Daniel C. Feldman. "When mergers force layoffs: Some lessons about managing the human resource problems." Human Resource Planning12.2 (1989): 123-140.

Leiter, Michael P., and Christina Maslach. "The impact of interpersonal environment on burnout and organizational commitment." Journal of organizational behavior 9.4 (1988): 297-308.

Marks, Mitchell Lee, and Philip H. Mirvis. "Track the impact of mergers and acquisitions." Personnel Journal 71.4 (1992): 70-79.

McCauley, D. P.,\& Kuhnert, K. W. 1992. A theoretical review and empirical investigation of employee trust in management. Public Administration Quarterly, 16: 265-284

Mishra, Jitendra, and Molly A. Morrissey. "Trust in employee/employer relationships: A survey of West Michigan managers." Public Personnel Management (1990).

Paulsen, Neil., et al. "Identification, discourse, and intergroup communication in organizational contexts." Unpublished manuscript, University of Queensland, Brisbane (2004).

Punch, Keith F. Introduction to social research: Quantitative and qualitative approaches. Sage, 2013.

Riordan, Christine M., and Elizabeth W. Weatherly. "Defining and measuring employees' identification with their work groups." Educational and Psychological Measurement 59.2 (1999): 310-324.

Schweiger, David M., and Angelo S. Denisi. "Communication with employees following a merger: A longitudinal field experiment." Academy of management journal34.1 (1991): 110-135.

Schweiger, David M., and James P. Walsh. "Mergers and acquisitions: An interdisciplinary view." Research in personnel and human resources management 8 (1990): 41-107.

Shrout, Patrick E., and Niall Bolger. "Mediation in experimental and nonexperimental studies: new procedures and recommendations." Psychological methods7.4 (2002): 422.

Smidts, Ale, Ad Th H. Pruyn, and Cees BM Van Riel. "The impact of employee communication and perceived external prestige on organizational identification." Academy of management journal 44.5 (2001): 1051-1062.

Tim A. Grice , Cynthia Gallois , Elizabeth Jones , Neil Paulsen \& Victor J. Callan (2006): "We Do It, but They Don't": Multiple Categorizations and Work Team Communication, Journal of Applied Communication Research, 34:4, 331348 
Turner, John C., et al. Rediscovering the social group: A self-categorization theory. Basil Blackwell, 1987.

Tüzün, İpek Kalemci, and İrfan Çağlar. "Örgütsel Özdeşleşme Kavramı ve İletişim Etkinliği İlişkisi." Journal of Yasar University 3.9 (2008): 1011-1027.

Vaara, E. (2003). 'Post-acquisition integration as sensemaking: Glimpses of ambiguity, confusion, hypocrisy, and politicization', Journal of Management Studies, 40, pp. 859-894.

van Dick, R., Ullrich J, Tissington, P.A., Working Under a Black Cloud: How to Sustain Organizational Identification after a Merger, British Journal of Management, Vol. 17, S69S79 (2006)

Van Knippenberg, D. and E. Van Leeuwen (2001). 'Sense of continuity as the key to postmerger identification'. In: M. A. Hogg and D. J. Terry (eds), Social identity processes in organizational contexts, pp. 249-264. Psychology Press, Philadelphia.

Van Knippenberg, Daan, and Naomi Ellemers. "Social Identity and Group Performance." Social identity at work: Developing theory for organizational practice (2003): 29.

www.kpmg.com/IN/en/IssuesAndInsights/ArticlesPublications/Documents/Post\%20Merger\%20Peopl e\%20Integration.pdf 24.12.2014 